\title{
APPLICATION OF MULTI CRITERIA DECISION MAKING TO URBAN PLANNING - A REVIEW
}

\author{
UDC: 005.311.6:711.4 \\ Review Paper \\ Ali Reza AFSHARI ${ }^{1}$, Mahdi VATANPARAST ${ }^{2}$, Dragan Ć Ó́KALO $^{3}$ \\ ${ }^{1}$ Islamic Azad University, Department of Industrial Engineering, Shirvan Branch, Shirvan, Iran \\ E-mail: afshari@mshdiau.ac.ir \\ ${ }^{2}$ Islamic Azad University, Department of Geography, Shirvan Branch, Shirvan, Iran \\ ${ }^{3}$ University of Novi Sad, Technical faculty "Mihajlo Pupin" Zrenjanin, 23000 Zrenjanin, Đure Đakovića bb, \\ Republic of Serbia
}

Paper received: 12.02.2016.; Paper accepted: 29.03.2016.

\begin{abstract}
Nowadays a wide range of operational and research activities in different fields of urban planning consist of decision making problems. Decision making is the main element in the analysis in regional studies and skills related to the success of the planning process. This paper has been written in the field of urban planning decision making. It provides a survey of the literature on multiple criteria decision making (MCDM) applications to urban planning problems. Articles were classified into four application areas and scopes. This research contributes to the existing literature on the urban planning and MCDM. It provides a unified source of references that could be useful for students, researchers and practitioners. The paper ends with an assessment of the literature presented, aiming to reach some conclusions, as well as indicate future trends in this line of research.
\end{abstract}

Key words: Decision making, Multi Criteria Decision Making (MCDM), Urban Planning.

\section{INTRODUCTION}

In the 1960s, the first multi-criteria decision making (MCDM) techniques emerged to alleviate difficulties in accommodating diverse opinions and handling large amounts of complex information in the decision-making process. These capabilities have encouraged planners to combine MCDM with other planning tools such as geographical information system (GIS). The methods of MCDM evolved as a response to the observed inability of people to effectively analyze multiple streams of dissimilar information. There are many different MCDM methods, and a detailed analysis of the theoretical foundations of these methods and their comparative strengths and weaknesses is presented in Belton and Steward (Belton \& Steward, 2002). The common purpose of MCDM methods is to evaluate and choose among alternatives based on multiple criteria using systematic analysis that overcomes the limitations of unstructured individual or group decision making. Within MCDM, elementary methods can be used to reduce complex problems to a singular basis for selection of a preferred alternative. Competing decision criteria may be present, but inter criteria weightings are not required. For example, an elementary goal aspiration approach may rank the dredging alternatives in relation to the total number of performance thresholds met or exceeded. While the analysis can, in most applications of elementary approaches, be executed without the help of computer software, these methods are best suited for problems with few alternatives and criteria, a condition that is rarely characteristic of urban projects. Multi-criteria decision making involves a multi-stage process of (i) defining objectives, (ii) choosing the criteria to measure the objectives, (iii) specifying alternatives, (iv)assigning weights to the criteria, and (v) applying the appropriate mathematical algorithm for ranking alternatives. MCDM allows to accommodate the need for unbiased integration of modern planning objectives for independent identification and ranking of the most suitable 
planning solutions (Mosadeghi, Tomlinson, Mirfenderesk, \& Warnken, 2009).

Modern planning theories encourage approaches that consider all stakeholders with a variety of discourse values to avoid political and manipulative decisions. In the last decade, application of quantitative approaches such as multi-criteria decision making techniques in urban planning procedures has increased. The use of multi criteria decision making in urban planning is the focus of this paper. The first aim of this paper is to review the decision making approaches for assessment in the context of urban management, The second aim is to identify shortcomings associated with the use of MCDM for assessing urban planning problems. In this paper, we attempted to show the important role of MCDM techniques in four areas of application for the urban planning: (1) Urban solid waste planning, (2) Urban land use planning, (3) Urban site selection, and (4) Urban water management.

\section{URBAN SOLID WASTE PLANNING}

Urban solid waste planning addresses situations which involve a variety of factors such as economic costs, legislative requirements, land use, pollution generation, resource usage and equity in the number and demographics of people effected by a plan. In making decisions about solid waste systems, the trade-offs between these factors must be considered, leading to large amounts of data and information that must be organized and analyzed. Unfortunately, many municipal solid waste planners do not have the resources needed to manage all relevant information, leading to incomplete consideration of relevant factors, or satisficing in selecting an alternative. An example application based on the search for suitable sites for the disposal of radioactive waste in the UK using the Arc/Info GIS is included by Carver (Carver, 1991). The potential use of a combined GIS-MCDM approach in the development of spatial decision support systems is considered in this research.

A specific spatial decision support system (SDSS) developed by MacDonald (1996)was created to address the multi-attribute and geographical nature of solid waste systems. The SDSS included expert systems and model management capabilities to supply, organize and analyze relevant data, and a GIS to help planners understand the spatial nature of particular programs and how they may impact the public and the environment.

Charnpratheep et al. (Charnpratheep et al., 1997) combained fuzzy set theory and the analytic hierarchy process (AHP) into a geographical information system (GIS) for the preliminary screening of landfill sites in Thailand. The theory of linguistic variable is used to represent imprecision of spatial data and human cognition over the criteria used for the screening process. Proximity of geographic objects, slope and elevation are criteria used for this investigation. The priority weights reflecting the preferences on the screening criteria, accounting for seventeen map layers, are derived by the method of the AHP. The general method of GIS intersection based on binary logic is conducted to compare with the fuzzy min-operator intersection and the proposed convex combination model.

Bobbio (Bobbio, 2002) experienced a deliberative democracy process in an area in the Province of Torino $(6829 \mathrm{~km} 2)$, Italy, where local communities were involved in a decision concerning the sitting of an incinerator and a landfill for MSW. The process lasted 17 months and ended with an agreed choice. The author worked on the third phase of the decision-making process (choosing the best alternative) considering 14 criteria for the incinerator and 13 criteria for the landfill. Vatalis and Manoliadis (Vatalis \& Manoliadis 2002) overlaid GIS digital maps to find the suitable landfill sites in Western Macedonia, Greece.

Leao et al. (Leao et al., 2004) presented a model to spatially and dynamically model the demand for and allocation of facilities for urban solid waste disposal in growing urban regions. Their model consists of a loose-coupled system that integrates GIS (geographic information systems) and cellular automata (CA) in order to give it spatial and dynamic capabilities. The model is combined of three sub-systems: (1) a CA-based model to simulate spatial urban growth over the future; (2) a spread-sheet calculation for designing waste disposal options and hence evaluating demand for landfill space over time; and (3) a model developed within a GIS to evaluate the availability and suitability of land for landfill over time and then simulate allocation of landfills in the available land. The proposed model has been tested and set up with data from a real source (Porto Alegre City, Brazil), and has successfully assessed the demand for landfills and their allocation over time under a 
range of scenarios of decision-making regarding waste disposal systems, urban growth patterns and land evaluation criteria.

Kontos et al. (Kontos et al.,2005) investigated the sitting of MSW landfills with a spatial multiple criteria analysis methodology in an area of 480 $\mathrm{km} 2$ in the Island of Lemnos, Greece. The authors worked on the macro sitting level considering 11 criteria. In particular, AHP was used to perform a pair-wise comparison based on a review of relevant landfill sitting literature. Kontos et al. used the pair wise comparison matrix and criteria weights vector to calculate the suitability index estimated using the method of simple additive weighting (SAW). Kontos et al. evaluated the suitability of the study region to select an optimal landfill site using a spatial MCDM methodology.

Sener et al. (Sener et al.,2006) used GIS and MCDM to determine appropriate landfill sites. Mahini and Gholamalifard (Gholamalifard,2006) described a MCDM method, called weighted linear combination (WLC), in a GIS environment to evaluate the suitability of the outskirts of Gorgan city (Iran) as a landfill site.

AHP techniques were used by Dey and Ramcharan (Dey \& Ramcharan, 2008) for the site selection of limestone quarry operations to support cement production in Barbados; by Gemitzi et al. (Gemitzi et al. ,2007), Kontos et al. (Kontos et al.,2005), and Sener et al. (Sener et al. ,2006) for ranking potential MSW landfill areas; and by Wang et al. (Wang et al.,2009b) combined with spatial information technologies for landfill site selection. The integration of GIS and AHP is a powerful tool to solve the landfill site selection problem.

AHP and TOPSIS were used by Oenuet and Soner (Oenuet\&Soner,2008) for solid waste transshipment site selection in Turkey. Delgado et al. (Delgado et al. ,2008) performed a land suitability analysis for MSW sanitary landfill sitting in an area of $400 \mathrm{~km} 2$ in the Cuitzeo Lake Basin, Mexico. The authors worked on the macro siting level considering 11 criteria. The authors did not use AHP but a Boolean logic model. In particular, panelists were asked to discuss the importance of the criteria, and provide a qualitative ranking subsequently transformed into quantitative weights normalized to one. Sumathi et al. (Sumathi et al.,2008) studied the sitting of MSW landfills using a MCDM and overlay analysis using a GIS in an area of $293 \mathrm{~km} 2$ in the district of
Pondicherry, India. The authors worked on the macro/micro-siting level considering 11 criteria. AHP was employed wherein a consistent weight set was extracted through the pair wise comparison by decision makers in their consideration of each factor against one another. Feedback from a team with expertise in multi disciplinary fields of local environmental management of the Pondicherry was sought in the process. Chang et al. (Chang et al.,2008) and Akbari et al. (Akbari et al.,2008) combined GIS and a convoluted MCDM process to select a landfill site. Nas et al. (Nas et al.,2008) selected an MSW landfill site for Konya, Turkey using GIS and an evaluation of several criteria. Chang et al. (Chang et al., 2008) presented a fuzzy multi-criteria decision analysis alongside with a geospatial analysis for the selection of landfill sites. It employs a two-stage analysis synergistically to form a spatial decision support system (SDSS) for waste management in a fastgrowing urban region, south Texas. The purpose of GIS was to perform an initial screening process to eliminate unsuitable land followed by utilization of FMCDM method to identify the most suitable site using the information provided by the regional experts with reference to five chosen criteria. Sensitivity analysis was performed using Monte Carlo simulation where the decision weights associated with all criteria were varied to investigate their relative impacts on the rank ordering of the potential sites in the second stage.

Wang et al. (Wang et al. 2009a) developed a case study on MSW landfill sitting using spatial information technologies and AHP in an area of $16807.8 \mathrm{~km} 2$ corresponding to the territory of Beijing, China. The authors worked on the macro sitting level considering 13 criteria. AHP was used to establish the relative importance of hierarchy elements. Decision-makers evaluated the importance of pairs of grouped elements in terms of their contribution to the higher hierarchy. Sharifi et al. (Sharifi et al.2009) integrated MCDM for a GIS-based hazardous waste landfill sitting in an area of $28,817 \mathrm{~km} 2$ corresponding to the Kurdistan Province, western Iran. The authors worked on the macro sitting level considering 14 non exclusionary criteria which were weighted with the 9-point rating system and using the information provided by regional experts. Guiqin et al. (Guiqin et al.,2009) used spatial information technologies and AHP for landfill site selection in Beijing, China. 
Geneletti (Geneletti,2010) proposed and tested an approach involving the stakeholders' opinion in an inert landfill sitting process in an area of $196 \mathrm{~km} 2$ in the south western part of Trentino, Italy.

\section{URBAN LAND USE PLANNING}

Urban planning analysis involves the consideration of a number of factors, including natural system constraints, compatibility with existing land uses, existing land use policies, and availability of community facilities. The suitability techniques analyze the interaction between location, development actions, and environmental elements to classify the units of observation according to their suitability for a particular use (Mosadeghi et al., 2015).

These spatial MCDM techniques are capable of improving the transparency and analytic rigour of the land use decisions (Mosadeghi, et al., 2015). Mosadeghi et al. (2015) used a case study to compare the outcomes of Analytical Hierarchy Process (AHP) and Fuzzy AHP in urban land use planning for the northeast Gold Coast located in Queensland on the east coast of Australia. A genetic algorithm was used by Balling et al. (Balling et al. ,1999) to search for optimal future land-use and transportation plans for a high-growth city. Millions of plans were considered. Constraints were imposed to ensure affordable housing for future residents. Objectives included the minimization of traffic congestion, the minimization of costs, and the minimization of change from the status quo. The genetic algorithm provides planners and decision makers with a set of optimal plans known as the Pareto set. The value of each plan in the Pareto set depends on the relative importance that decision makers place on the various objectives.

Chen et al. (Chen et al.,2010) presented a GISbased MCDM model for land suitability evaluation. A methodology was developed to perform simulations where the weights associated with all criteria used for suitability modelling were varied one-at-a-time (OAT) to investigate their relative impacts on the final evaluation results. A tool which incorporates the OAT method with the Analytical Hierarchy Process (AHP) within the ArcGIS environment was implemented. A case study of irrigated cropland suitability assessment addressing the application of the new GIS-based AHP-SA tool is described.
Arciniegas et al. (Arciniegas et al.,2011) focused on the use of map-based multi-criteria analysis to develop a negotiation support tool for land use allocation. Spatial multi-criteria analysis is used to make explicit trade-offs between objectives and to provide guidance and feedback on the land use changes negotiated by the participants. The approach is tested during a negotiation session as part of the land use planning process of the Bodegraven polder, a peat meadow area in the Netherlands.

Mosadeghi et al. (Mosadeghi et al.,2015) compared the results of two quantitative techniques (analytical hierarchy procedure (AHP) and Fuzzy AHP in defining the extent of land-use zones at a large scale urban planning scenario.

\section{URBAN SITE SELECTION}

One of the most common GIS based strategies that were designed to facilitate decision making in site selection is MCDM. The Analytic Hierarchy Process (AHP) method, originally developed by Saaty (Saaty,1980), is a flexible and easily implemented MCDM technique and its use was largely explored in the literature with many examples in locating facilities (Dey \& Ramcharan, 2008; Kontos, et al., 2005; Wang, et al., 2009b). Hansen (Hansen, 2005) presents a GIS based MCDM to identify the best sites for the construction of new wind farms. Zambon et al. (Zambon et al.,2005) describe a GIS based MCDM method for evaluating alternative places for the location of thermoelectric power plants in Sao Paulo state (Brazil). Gemitzi et al. (Gemitzi et al.2007) have used a groundwater vulnerability index including a five discrete groundwater vulnerability classes in order to assess alternative choices for hazardous landfill sites. Integrating land suitability analysis in urban greenery was further investigated by Zucca et al. (Zucca et al.,2008). They investigated a site selection process for setting up a local park. Radiarta, et al. (Radiarta, et al.,2008) demonstrated the use of GIS to model site selection for scallop culture in Funka Bay based on a certain important criteria and showed acceptable results. Nobre et al. (Nobre et al.,2009) described a geo spatial multi criteria methodology, based on geographic information systems technology, for identification of the best location to deploy a wave energy farm. 


\section{A. R. Afshari et al. Application of multi criteria decision making to urban planning - A review}

\section{URBAN WATER MANAGEMENT}

Urban water management is a demanding decisionmaking environment where optimal planning presupposes a synthesis of heterogeneous information of high spatial resolution to ensure site-specific implementation.

Makropoulos et al. (Makropoulos et al.,2003) developed a prototype spatial decision support system (SDSS) supporting strategic planning, providing examples from a particular application in water demand management (WDM). The results support the case of using SDSS based on approximate reasoning to complement engineering expertise for urban water management applications tailored to user characteristics and site-specific constraints.

Integrated sustainability assessment is part of a new paradigm for urban water decision making. Multi-criteria decision making (MCDM) is an integrative framework used in urban water sustainability assessment, which has a particular focus on utilising stakeholder participation (Lai et al., 2008).

Five Multi-criterion Decision Making (MCDM) methods, namely, ELECTRE-2, PROMETHEE-2, Analytic Hierarchy Process (AHP), Compromise Programming (CP) and EXPROM-2 are employed by Raju and Pillai (Raju \& Pillai,1999) to select the best reservoir configuration for the case study of Chaliyar river basin, Kerala, India. Spearman rank correlation coefficient is used to assess the correlation between the ranks obtained by the above MCDM methods.

A fuzzy compromise approach to decision analysis is described within the context of water resource systems planning under uncertainty by Bender and Simonovic (Bender \& Simonovic,2000). The approach allows various sources of uncertainty and is intended to provide a flexible form of group decision support. The example compares the ELECTRE method with the fuzzy compromise approach. The comparison is intended to demonstrate the benefits of adopting a multicriteria decision analysis technique which presents subjectivity within its proper context while maintaining an intuitive and transparent technique for ranking alternatives.

Nayak and Panda (Nayak \&Panda, 2001) used multi-criteria (multi-objective) technique in solving some complex problems related to water resource management in India. Five objectives were considered in the study. The benefit of combining these objective functions with the decision support tool is that the management of land and water resources can be made more effectively. Based on this concept, a methodology was developed through this study, for the water managers and decision-makers, to obtain a compromising solution in terms of area allocated under different crops and the magnitude of farming system variables in a canal command area. This study was undertaken in the Mahanadi Delta of India. Multi-objective techniques such as Sequential Linear Fuzzy Programming and Goal Programming were used for their simplicity in computation and flexibility in application.

Simon and Bruggemann (Simon \& Bruggemann, 2004) demonstrated the evaluation of water management strategies in the cities of Berlin and Potsdam (Germany) with respect to their ecological effects. Two decision support systems were compared, namely PROMETHEE, which is designed to obtain a clear decision (linear ranking), and Hasse Diagram Technique (HDT), normally providing more than one favourable solution.

Abrishamchi and Ebrahimian (Abrishamchi \& Ebrahimian 2005) attempted to put into practice the multi-criteria decision making technique of compromise programming for a real urban water management case study in the city of Zahidan in Iran. To satisfy future water demands, a longdistance water transmission project is being implemented. Compromise programming is applied to aiding decision makers in selecting the best possible alternatives for distribution of both available and the transmitted water in the city. Malmqvist and Palmquist (Malmqvist \& Palmquist ,2005) developed a decision support tool to facilitate the selection of combinations of water saving strategies and technologies and to support the delivery of integrated, sustainable water management for new developments. The technology selection is driven by a GA algorithm allowing efficient exploration of the decision space. Quantitative and qualitative sustainability criteria and indicators are used to compare between alternative composite water management strategies while preserving the multi-objective nature of the problem. The tool has been successfully tested on a case study site in the UK, and the results are presented and discussed. 
Morais and Almeida (Morais \& Almeida 2007) described the application of multi-criteria decision aid for choosing the priority city to receive a water supply system, using the ELECTRE methodology. Makropoulos and Argyrou (Makropoulos \& Argyrou 2007) developed a spatial decisionsupport tool based on soft computing that assists the optimal siting of wastewater treatment technologies within the context of new urban developments, through the creation of suitability maps. The tool was based on multi-criteria decision analysis and fuzzy logic, allowing the inclusion of both uncertainty and of the decisionmakers' attitude towards risk in the decisionmaking process. The research described the attributes influencing the siting of wastewater treatment infrastructure and presents a method for using these to generate composite siting suitability maps for a given development site and propose specific locations maximizing the combined suitability index. Extensive sensitivity analysis has been undertaken and the results discussed. The proposed system architecture integrated three widely used software platforms (ArcView GIS, Matlab and MS Excel) into a flexible and userfriendly decision-support tool that can easily be adapted to different spatial decision environments.

\section{CONCLUSIONS}

This study aimed to review papers that used the MCDM techniques and approaches for urban planning in 4 different areas of application which were published before 2016. This study attempted to categorize these papers into 4 application areas and scopes: (1) Urban solid waste planning, (2) Urban land use planning, (3) Urban site selection, and (4) Urban water management. The results obtained from this review show that MCDM approaches and techniques are appropriate for the urban planning problems. Each approach and technique may have some drawbacks and advantages, and it cannot be claimed that a particular approach or technique is more appropriate than the others. Various DMs generally disagree on the approach and technique, which is the most valid and suitable. The selection of an approach and technique is mostly dependent upon the preferences of DM and the analyst. The methods must be taken into consideration in terms of validity, suitability, and user-friendliness. In addition, it should be realized that employing different approaches and techniques will most likely lead to different recommendations, and it is noteworthy that there may be errors in any approach or technique. The contributions of the study results to the existing literature on the urban planning and MCDM issues were addressed and the results were provided to academic scholars and leaders of organizations and industries in the field of service quality evaluation, enabling them to improve their planning processes by identifying relevant urban planning attributes and assessing their impact on the urban planning.

This particular paper has some limitations and recommendations for future studies. First of all, this study categorized 4 application areas and scopes. It is recommended for future studies to review papers in different sub-areas of urban planning categories. Another limitation is that the data were collected from journals, and the documents do not include textbooks, doctoral and master's dissertations and theses, and unpublished papers on MCDM issues. As a result, in a future study, data can be collected from these sources, and the obtained results can be compared to the results obtained and reported in this study. The next limitation is that all of the papers were extracted from journals in English; then, the scholarly journals published in other languages were not included in this review. However, the researchers believed that this paper comprehensively reviewed and included most of the papers, which were published in international journals. This paper carefully selected and summarised the available papers of several publishers in Web of Science, Scopus, and Google Scholar. Though, a number of relevant outlets might have remained beyond the scope of the current study. Therefore, future studies could review the papers that were not used in the current review. As another limitation, the paper presents the review of numerous publications, which describe the use of MCDM recently-developed methods in journals. However, this review does not cover recent methods that have been published in books.

\section{REFERENCES}

Abrishamchi, A., Ebrahimian, A., Tajrishi, M., \& Mario, M. A. (2005). Case study: application of multicriteria decision making to urban water supply. Journal of Water Resources Planning and Management, 131(4), 326-335.

Akbari, V., Rajabi, M., Chavoshi, S., \& Shams, R. (2008). Landfill Site Selection by Combining GIS and Fuzzy Multi-Criteria Decision Analysis, Case Study: Bandar Abbas, Iran. World Applied Sciences, 3(1), 39-47. 
Arciniegas, G., Janssen, R., \& Omtzigt, N. (2011). Mapbased multicriteria analysis to support interactive land use allocation. International Journal of Geographical Information Science, 25(12), 19311947.

Balling, R. J., Taber, J. T., Brown, M. R., \& Day, K. (1999). Multiobjective urban planning using genetic algorithm. Journal of Urban Planning and Development, 125(2), 86-99.

Belton, V., \& Stewart, T. (2002). Multiple criteria decision analysis: an integrated approach: Springer Science \& Business Media.

Bender, M. J., \& Simonovic, S. P. (2000). A fuzzy compromise approach to water resource systems planning under uncertainty. Fuzzy sets and systems, 115(1), 35-44.

Bobbio, L. (2002). Smaltimento dei rifiuti e democrazia deliberativa.

Carver, S. J. (1991). Integrating multi-criteria evaluation with geographical information systems. International Journal of Geographical Information System, 5(3), 321-339.

Chang, N.-B., Parvathinathan, G., \& Breeden, J. B. (2008). Combining GIS with fuzzy multicriteria decision-making for landfill siting in a fast-growing urban region. Journal of Environmental Management, 87(1), 139-153.

Chang, N. B., Parvathinathan, G., \& Breeden, J. B. (2008). Combining GIS with fuzzy multicriteria decision-making for landfill siting in a fast-growing urban region. Journal of Environmental Management, 87(1), 139-153.

Charnpratheep, K., Zhou, Q., \& Garner, B. (1997). Preliminary landfill site screening using fuzzy geographical information systems. Waste management \& research, 15(2), 197-215.

Chen, Y., Yu, J., \& Khan, S. (2010). Spatial sensitivity analysis of multi-criteria weights in GIS-based land suitability evaluation. Environmental Modelling \& Software, 25(12), 1582-1591.

Delgado, O. B., Mendoza, M., Granados, E. L., \& Geneletti, D. (2008). Analysis of land suitability for the siting of inter-municipal landfills in the Cuitzeo Lake Basin, Mexico. Waste Management, 28(7), 1137-1146.

Dey, P. K., \& Ramcharan, E. K. (2008). Analytic hierarchy process helps select site for limestone quarry expansion in Barbados. Journal of Environmental Management, 88(4), 1384-1395.

Gemitzi, A., Tsihrintzis, V., Voudrias, E., Petalas, C., \& Stravodimos, G. (2007). Combining geographic information system, multicriteria evaluation techniques and fuzzy logic in siting MSW landfills. Environmental Geology, 51(5), 797-811.

Geneletti, D. (2010). Combining stakeholder analysis and spatial multicriteria evaluation to select and rank inert landfill sites. Waste Management, 30(2), 328337.

Hansen, H. S. (2005). GIS-based multi-criteria analysis of wind farm development. Paper presented at the
Proceedings of the 10th Scandinavian Research Conference on Geographical Information Science.

Kontos, T. D., Komilis, D. P., \& Halvadakis, C. P. (2005). Siting MSW landfills with a spatial multiple criteria analysis methodology. Waste Management, 25(8), 818-832.

Lai, E., Lundie, S., \& Ashbolt, N. (2008). Review of multi-criteria decision aid for integrated sustainability assessment of urban water systems. Urban water journal, 5(4), 315-327.

Leao, S., Bishop, I., \& Evans, D. (2004). Spatialâ€"temporal model for demand and allocation of waste landfills in growing urban regions. Computers, Environment and Urban Systems, 28(4), 353-385.

MacDonald, M. L. (1996). A multi-attribute spatial decision support system for solid waste planning. Computers, Environment and Urban Systems, 20(1), 1-17.

Mahini, A. S., \& Gholamalifard, M. (2006). Siting MSW landfills with a weighted linear combination methodology in a GIS environment. International Journal of Environmental Science and Technology, 3(4), 435-445.

Makropoulos, C., Argyrou, E., Memon, F., \& Butler, D. (2007). A suitability evaluation tool for siting wastewater treatment facilities in new urban developments. Urban water journal, 4(2), 61-78.

Makropoulos, C., Butler, D., \& Maksimovic, C. (2003). Fuzzy logic spatial decision support system for urban water management. Journal of Water Resources Planning and Management, 129(1), 6977.

Malmqvist, P.-A., \& Palmquist, H. (2005). Decision support tools for urban water and wastewater systems- focussing on hazardous flows assessment. Water Science \& Technology, 51(8), 41-49.

Morais, D. C., \& Almeida, A. T. (2007). Water supply system decision making using multicriteria analysis. Water SA, 32(2), 229-236.

Mosadeghi, R., Tomlinson, R., Mirfenderesk, H., \& Warnken, J. (2009). Coastal management issues in Queensland and application of the multi-criteria decision making techniques. Journal of coastal research, 1252-1256.

Mosadeghi, R., Warnken, J., Tomlinson, R., \& Mirfenderesk, H. (2015). Comparison of FuzzyAHP and AHP in a spatial multi-criteria decision making model for urban land-use planning. Computers, Environment and Urban Systems, 49, 54-65.

Nayak, R., \& Panda, R. (2001). Integrated management of a canal command in a river delta using multiobjective techniques. Water resources management, 15(6), 383-401.

Nobre, A., Pacheco, M., Jorge, R., Lopes, M. F. P., \& Gato, L. M. C. (2009). Geo-spatial multi-criteria analysis for wave energy conversion system deployment. Renewable Energy, 34(1), 97-111. 
Radiarta, I. N., Saitoh, S. I., \& Miyazono, A. (2008). GIS-based multi-criteria evaluation models for identifying suitable sites for Japanese scallop (Mizuhopecten yessoensis) aquaculture in Funka Bay, southwestern Hokkaido, Japan. Aquaculture, 284(1-4), 127-135.

Raju, K. S., \& Pillai, C. (1999). Multicriterion decision making in river basin planning and development. European Journal of Operational Research, 112(2), 249-257.

Saaty, T. L. (1980). The Analytic Hierarchy Process. New York: McGraw-Hill.

Sener, B., Suzen, M. L., \& Doyuran, V. (2006). Landfill site selection by using geographic information systems. Environmental Geology, 49(3), 376-388.

Sharifi, M., Hadidi, M., Vessali, E., Mosstafakhani, P., Taheri, K., Shahoie, S., et al. (2009). Integrating multi-criteria decision analysis for a GIS-based hazardous waste landfill sitting in Kurdistan Province, western Iran. Waste Management, 29(10), 2740-2758.

Simon, U., Bruggemann, R., \& Pudenz, S. (2004). Aspects of decision support in water managementâ€"example Berlin and Potsdam (Germany) Iâ€"spatially differentiated evaluation. Water Research, 38(7), 1809-1816.

Sumathi, V. R., Natesan, U., \& Sarkar, C. (2008). GISbased approach for optimized siting of municipal solid waste landfill. Waste Management, 28(11), 2146-2160.

Vatalis, K., \& Manoliadis, O. (2002). A two-level multicriteria DSS for landfill site selection using GIS: case study in western Macedonia, Greece. Journal of Geographic Information and Decision Analysis, 6(1), 49-56.

Wang, G., Qin, L., Li, G., \& Chen, L. (2009a). Landfill site selection using spatial information technologies and AHP: A case study in Beijing. China. Journal of Environmental Management, 90(8), 2414-2421.

Wang, G., Qin, L., Li, G., \& Chen, L. (2009b). Landfill site selection using spatial information technologies and AHP: A case study in Beijing, China. Journal of Environmental Management, 90(8), 2414-2421.

Zambon, K. L., Carneiro, A. A. F. M., Silva, A. N. R. S., \& Negri, J. C. (2005). Anaİ $\square$ lise de decisal̀fo multicriteİ $\square$ rio na localizacİ§aİfo de usinas termoele $\square$ ctricas usando SIG.

Zucca, A., Sharifi, A. M., \& Fabbri, A. G. (2008). Application of spatial multi-criteria analysis to site selection for a local park: A case study in the Bergamo Province, Italy. Journal of Environmental Management, 88(4), 752-769.

\title{
PRIMENA VIŠEKRITERIJUMSKOG ODLUČIVANJA NA URBANIZAM - PREGLED
}

\begin{abstract}
Danas širok spektar operativnih i istraživačkih aktivnosti u različitim oblastima urbanističkog planiranja sadrži probleme odlučivanja. Odlučivanje je glavni element u analizi u regionalnim studijama i razvoju veština vezanih za uspeh procesa planiranja. Ovaj rad se odnosi na oblasti odlučivanja u urbanizmu i daje pregled literature o primeni višekriterijumskog odlučivanja na urbanističke probleme. Članci su razvrstani u četiri područja primene i okvira. Ovo istraživanje doprinosi postojećoj literaturi o planiranju u urbanizmu i višekriterijumskom odlučivanju. Takođe predstavlja jedinstven izvor referenci koje bi mogle biti korisne za studente, istraživače i praktičare. Rad se završava sa procenom predstavljene literature, sa ciljem da se postignu neki zaključci, kao i ukaže na buduće trendove u ovoj oblasti istraživanja.
\end{abstract}

Ključne reči: Odlučivanje, Višekriterijumsko odlučivanje, Urbano planiranje. 